\section{Effect of mechanical treatment on properties of Si-Al-O zeolites}

AleXANDR Y. BUZIMOV - Institute of Strength Physics and Materials Science SB RAS, National Research Tomsk State University - buzimov92@gmail.com

WILHELM ECKL - Fraunhofer Institute for Chemical Technology ICT

LÁszLó A. GÖMZE - Institute of Ceramics and Polymer Engineering, University of Miskolc- femgomze@uni-miskolc.hu

ISTVÁN KOCSERHA - Institute of Ceramics and Polymer Engineering, University of Miskolc = istvan.kocserha@uni-miskolc.hu

EMESE KUROVICS - Institute of Ceramics and Polymer Engineering, University of Miskolc - fememese@uni-miskolc.hu

ALEKSEY S. KULKOV - Institute of Strength Physics and Materials Science SB RAS, National Research Tomsk State University

SERGEI N. KULKOV - Institute of Strength Physics and Materials Science SB RAS, National Research Tomsk State University - kulkov@ms.tsc.ru

Érkezett: 2018. 01. 15. - Received: 15. 01. 2018. " https://doi.org/10.14382/epitoanyag-jsbcm.2018.5

\section{Abstract}

In the work the results influence of mechanical treatment on morphology, specific surface area, and phase composition of natural zeolite of Tokaj Mountain deposits, synthetic zeolites SAPO34, SCT-323 are presented. Specific surface area of the synthetic zeolites decreases during the mechanical activation in a planetary ball mill. The changes of the specific surface area of the natural zeolites corresponds to the curve of the developed specific surface as function of the milling time (rittinger-zone, aggregation-zone and agglomeration-zone). During the mechanical activation, it was observed an increase of system amorphisation by $8-10 \%$ for synthetic zeolites, by $40-45 \%$ for natural zeolite. Results obtained represent scientific and practical interest, which can be used for further studies zeolites.

Keywords: crystal structure, mechanical activation, morphology, X-ray diffraction, zeolite
Alexandr Y. BUZIMOV, is graduated in the National Research Tomsk State University, as an engineer physic and he actually continues his study as PhD student under supervision of Prof. S. N. Kulkov in the Institute of Strength Physics and Materials Science SB RAS.

Wilhelm ECKL, is professor and head of Energetic Systems Department at the Fraunhofer ICT

László A. GÖMZE, is establisher and professor of the Department of Ceramics and Silicate Engineering in the University of Miskolc, Hungary. He is author or coauthor of 2 patents, 6 books and more than 300 scientific papers. Recently, he is the chair of the International Organization Board of ic-cmtp5 the 5th International Conference on Competitive Materials and Technological Processes (2018).

István KOCSERHA, is graduated in the University of Miskolc and has PhD since 2010. At present he is associate professor and chair of the Department of

Ceramics and Silicate Engineering (DCSE) in University of Miskolc (Hungary). He is author or co-author of 35 articles and 1 Hungarian patent.

Emese KUROVICS, is graduated in the University of Miskolc, Department of Ceramics and Silicate Engineering as a material engineer, where she actually continues her study as PhD student under supervision of Prof. L. A. Gömze.

Aleksey S. KULKOV, 1. Introduction

Zeolites are crystalline aluminosilicate materials having microporous (zeolite pore) in their structure. They are made of various compounds of $\mathrm{TO} 4(\mathrm{~T}=\mathrm{Si}$ or $\mathrm{Al})$ tetrahedral which result in the various zeolite pore sizes and structures [1]. The interest of researchers towards zeolites is connected with their unique properties: an extremely high adsorption capacity, catalyzing action, thermal stability and resistance in different chemical environments [2].

The results of the study of structural, physicochemical properties of zeolites allow developing the theoretical bases for the directed change of useful properties of natural minerals that are required for sorption materials [3].

The specific surface area is a dominant parameter for zeolites [4]. Obtain the necessary magnitude of specific surfaces of materials depends not only on their chemical and mineralogical composition, but also on physical, mechanical and rheological parameters of the used materials $[5,6]$. It is known that mechanical processing in activator mills can change the structure, specific surface area, crystal composition of zeolite containing materials and occasionally improve their processing properties [7]. In spite of the numerous publications, the physicochemical properties of natural zeolites are still not sufficiently studied.

The objective of this work was to study changes induced by mechanical activation on morphology, specific surface area, and phase composition of the zeolites. is physicist and has got PhD scientific degree at Tomsk State University in Russian Federation. At present he is working as research fellow at Institute of Strength Physics and Materials Science of the Russian Academy of Sciences in Tomsk.

Sergei N. KULKOV, is professor of the Tomsk State University and head of Department of Ceramics in the Institute of Strength Physics and Materials Science of the Russian Academy of Science since 1989. His research works are represented in 5 books, more than 150 articles, 18 patents and many International Symposiums and Conferences. At present he is head of department "Theory of Strength and Mechanic of Solids", member of "The American Ceramic Society” of "The APMI International" and the DYM AT Society (France).

\section{Materials and Experimental Procedure}

We used natural zeolite from the Tokaj Mountain deposits, and two commercial zeoliteSAPO-34 and SCT-323 which are chabazite's structural analog from the silicoaluminophosphate group samples of chabazite, differing in elemental composition.

Mechanical activation of the zeolites was performed in a planetary ball mill for 600 minutes. The acceleration in planetary mill was $26.8 \mathrm{~g}$. Ceramic grinding balls were used in planetary mill [8].

The crystal structure and phase composition of the zeolite before and after the mechanical activation were determined by X-ray diffraction analysis (XRD) using diffractometer Rigaku MiniFlex II with $\mathrm{Cu}-\mathrm{Ka}(\lambda=1.5418 \AA)$ radiation [9]. The phases were determined by search method using powder diffraction data base file PDF2.

The morphology of the powder was analyzed using scanning electron microscopy Zeiss Supra 55VP. 
The particle size was determined by using laser diffraction particle size analyzer Horiba LA-950 in the range 0.01 - 3000 $\mu \mathrm{m}$.

Brunauer, Emmett, Teller (BET) surface area was determined using a micrometrics Tristar 3000 gas adsorption analyzer [10].

\section{Results and Discussion}

\subsection{Initial powders}

$\begin{array}{ccccccccc}\text { Zeolite } & \text { OK } & \text { AIK } & \text { SiK } & \text { PK } & \text { TiK } & \text { MgK } & \text { CaK } & \text { FeK } \\ \text { Natural } & 48.56 & 3.76 & 46.28 & - & - & 0.25 & 0.55 & 0.60 \\ \text { SAPO-34 } & 35.60 & 48.03 & 03.06 & 13.32 & - & - & - & - \\ \text { SCT-323 } & 48.88 & 23.77 & 03.84 & 22.43 & 01.08 & - & - & -\end{array}$

Table 1. Chemical composition of the zeolites ( $w t \%$ )

1. táblázat A vizsgált zeolitok kémiai összetétele (m\%)

The results of elemental analysis (Table 1) showed that the natural zeolite powder in the initial state consisted of $\mathrm{Al}, \mathrm{O}$, $\mathrm{Si}, \mathrm{Ca}, \mathrm{Mg}, \mathrm{Fe}$. Synthetic zeolites contain a high Al content and low Si content. Zeolite SCT-323 containing titanium and relatively high content phosphorus is different from SAPO-34.

On Figure 1, figure 2 it is shown SEM-pictures and X-ray patterns of SAPO-34 and natural zeolite.

The SEM data showed that particles of natural zeolite powders has irregular shapes with an average particle size of $27 \mu \mathrm{m}$. Compared with natural zeolite particles of synthetic zeolite powders are closely matched and have shapes close to cubic with an average particle size $1.7 \mu \mathrm{m}$ for SAPO-34, $1.5 \mu \mathrm{m}$ for SCT-323.

Calculations of the X-ray pattern of natural zeolites showed that the structure of zeolite consists of seven different phases: smectite $15 \mathrm{~A} 20 \%$, quartz $8 \%$, low-cristobalite $15 \%$, clinoptilolite $14 \%$, illite $2 \mathrm{M} 115 \%$, orthoclase $9 \%$, calcite $6 \%$, amorphous phase $13 \%$.

Structure of synthetic zeolites consisting Aluminum Silicate Phosphate (PDF-2 00-047-0630). Amorphous phase in zeolites, in an amount $83 \%$ for SAPO-34, 85\% for SCT-323.
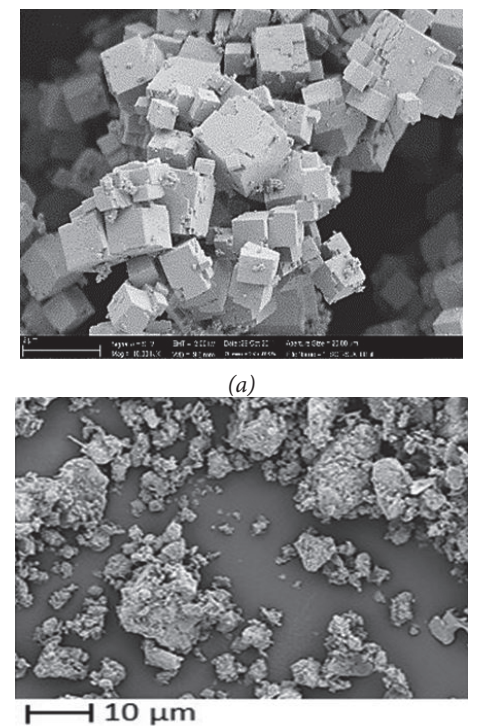

(b)

Fig. 1. SEM-picture, for (a) SAPO-34, (b) for natural zeolites 1. ábra A (a) SAPO-34 és a (b) természetes zeolitok SEM felvétele

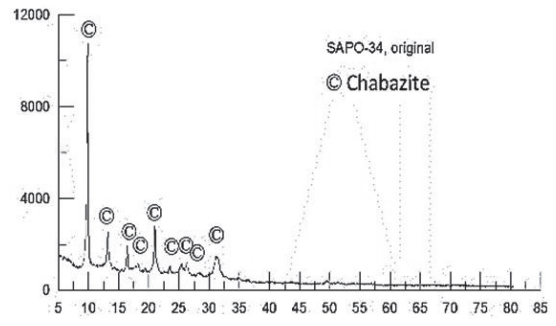

(a)

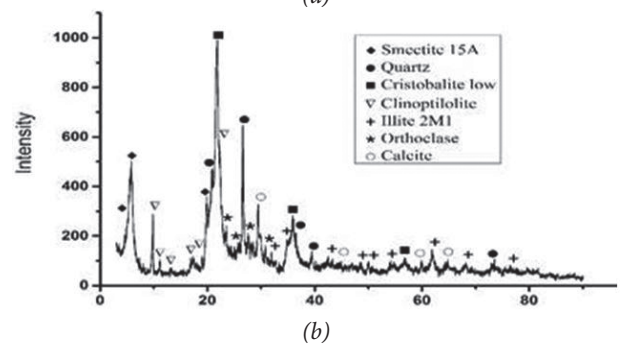

Fig. 2. X-ray pattern, for (a) SAPO-34, (b) for natural zeolites

2. ábra A (a) SAPO-34 és a (b) természetes zeolitok röntgendiffraktogram felvétele

\subsection{Mechanical activation}

Synthetic zeolites have initial high specific surface area (561 $\mathrm{m}^{2} / \mathrm{g}$ for SAPO-34, $573 \mathrm{~m}^{2} / \mathrm{g}$ for SCT-323) compared with natural zeolite $\left(19 \mathrm{~m}^{2} / \mathrm{g}\right)$.

Experimental results regarding the change in BET specific surface area of zeolite samples with mechanical activation time in a planetary ball mill are shown in figure 3.

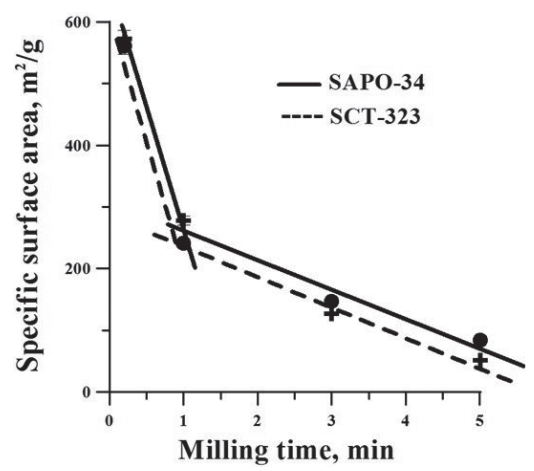

(a)

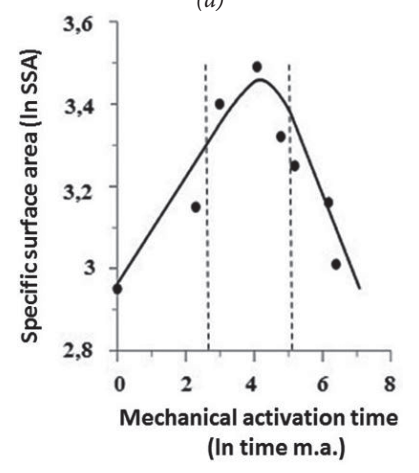

(b)

Fig. 3. The dependence of specific surface area values of zeolites from milling times (a) for synthetic zeolites, (b) for natural zeolite

3. ábra A zeolitok fajlagos felületének függése az örlési időtöl (a) szintetikus és (b) természetes zeolit esetén

During the first 60 minutes, the specific surface area of natural zeolite powder increases, reaching $33 \mathrm{~m}^{2} / \mathrm{g}$. After 120 minutes, the specific surface slightly decreases and after 600 minutes of activation, there is a significant reduction to $20 \mathrm{~m}^{2} / \mathrm{g}$. 
For synthetic zeolites are observed fast and sharp decrease specific surface area of the zeolites decreases during the milling.

During the 1 minute, the specific surface area of synthetic zeolite powder rapidly decreases, reaching $241 \mathrm{~m}^{2} / \mathrm{g}$ for SAPO34 and $278 \mathrm{~m}^{2} / \mathrm{g}$.

After this period decreases with prolonging the milling time, so it can be assumed that the minimum values of the specific surface area are achieved after 5 minutes of milling. The values of specific surface area of zeolite samples activated for $5 \mathrm{~min}$ were $83 \mathrm{~m}^{2} / \mathrm{g}$ for SAPO-34 and $51 \mathrm{~m}^{2} / \mathrm{g}$ for SCT-323.

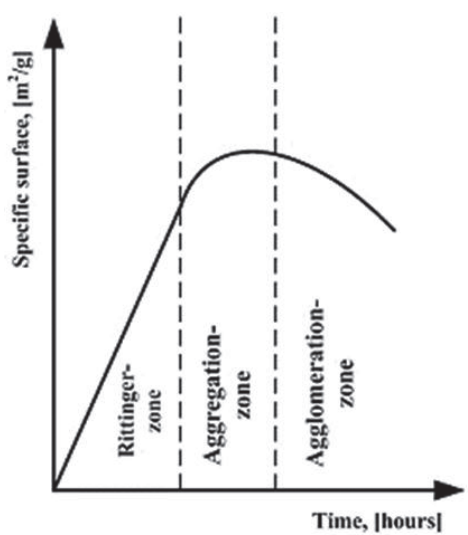

Fig. 4. Theoretical curve of specific surface as function of grinding time 4. ábra A fajlagos felület és az örlési idö kapcsolata

The theoretical curve of developed specific surface as function of grinding time is shown in Figure 4 [10]. Three wellshaped curves can be observed representing this theoretical curve. They are: Rittinger-zone: the increase of the specific surface is proportional to the grinding time; Aggregationzone: the intensity with which the increase of the specific surface decreases with the grinding time; Agglomeration-zone: the specific surface decreases with the comminution time [11]. The changes of the specific surface area of the natural zeolites corresponding to the theoretical curve.

Because of the small particle size of synthetic zeolite SAPO34 and SCT-323 with the increase in milling time takes place to agglomeration of particles only. Specific surface area of synthetic zeolites correspond to the agglomeration-zone on theoretical curve.

With the increase in the mechanical activation time there is also a change in the particles size of zeolite powders, as shown in figure 5.

The initial of natural zeolite-average was $27 \mu \mathrm{m}$. After activation of 20 minutes, particle size was $5.5 \mu \mathrm{m}$ and after 600 minutes of milling time, the particle size became $28 \mu \mathrm{m}$. Most particles have lost their initial shape and converted into a spherical shape during the mechanical activation [12,13].

With the increase in milling time, the particles size of synthetic zeolites decreased. Moreover most particles have lost their initial cubic shape and converted into spherical and also irregular shapes during the milling process on different milling times. The zeolite-average was $1.7 \mu \mathrm{m}$ for SAPO-34, $1.5 \mu \mathrm{m}$ for SCT-323. Then, after milling treatment at 1 minute the zeoliteaverage was $1.5 \mu \mathrm{m}$ for SAPO-34 and $1.2 \mu \mathrm{m}$ for SCT-323, after milling treatment at 5 minute the zeolite-average was $0.9 \mu \mathrm{m}$ for SAPO-34 and $0.7 \mu \mathrm{m}$ for SCT-323.

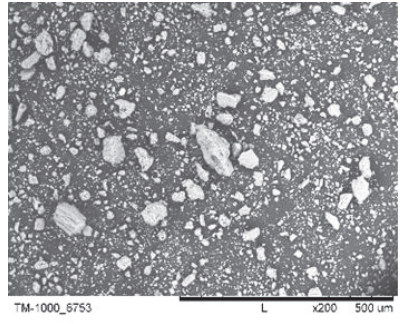

(a)

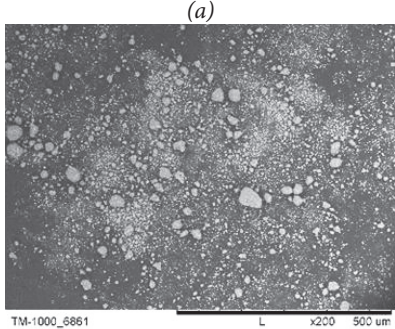

(b)

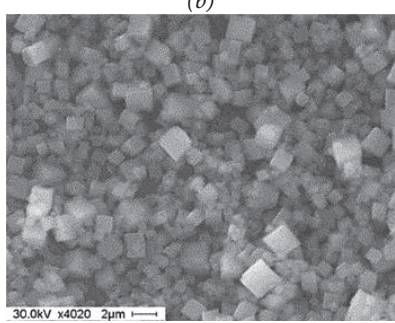

(c)

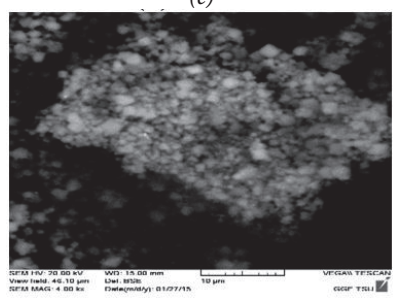

(d)

Fig. 5. SEM-pictures, initial of natural zeolite (a), after 600 minutes (b), initial of SAPO-34 (c), after 5 minutes (d) of milling time in a planetary ball mill

5. ábra A bolygó golyósmalomban történő őrléskor a természetes zeolit (a) kezdeti és (b) 600 perces örlés utáni illetve a SAPO-34 (c) kezdeti és (d) 5 perces örlés követöen kapott minták SEM felvételei

Selected XRD patterns of mechanically activated of synthetic zeolite powders and change mineralogical composition of natural zeolite during mechanical activation are shown in Figure 6.

All of the diffraction peaks of synthetic zeolites decreased and/or disappeared with the increase of mechanical activation time.

In addition, amorphisation occurred and an increase in amorphisation was observed, from 83 to $90 \%$ for SAPO-34 and from $85 \%$ to $93 \%$ for SCT-323. The tendency of the peaks that belong to the zeolite phase Aluminum Silicate Phosphate to disappear and this tendency increased with the milling time.

The quantitative analysis of XRD patterns showed radical changes in mineralogical compositions, as shown in figure 5 (c). The proportions of all mineralogical components of natural zeolite changed in dependence on the activation time. The most intensive changes can be observed in mineral components of smectite $15 \mathrm{~A}$, clinoptilolite, illite 2M1 and calcite. After 60 minutes of milling time the content of smectite 15 A - decreased from $20 \%$ to $10 \%$, clinoptilolite from $14 \%$ to 
9\%, meanwhile the amount of orthoclase - grew from 9\% to $12 \%$. In mineralogical composition, the considerable changes continued up to 600 minutes of mechanical activation. At 600 minutes of activation time the zeolite content of smectite 15 A, clinoptilolite, illite $2 \mathrm{M} 1$, and calcite reached its minimum value of $0.5 \%, 1 \%, 3 \%, 1 \%$ respectively, meanwhile the amount of quartz increased up to $17 \%$. Under mechanical activation the amount of quartz, low-cristobalite, orthoclase mineral components were also not stable, but their content have varied not so strong. In addition, during the mechanical activation it occurred amorphisation, which increase from $13 \%$ to $52 \%$.

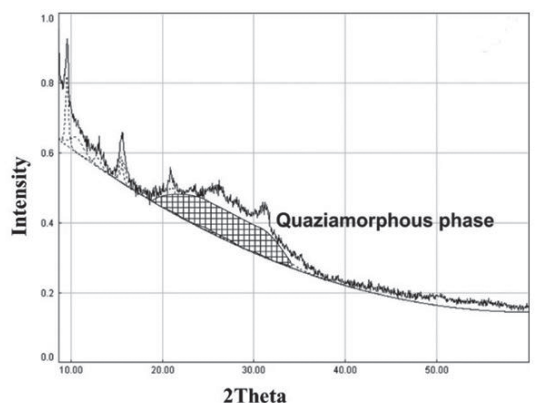

(a)

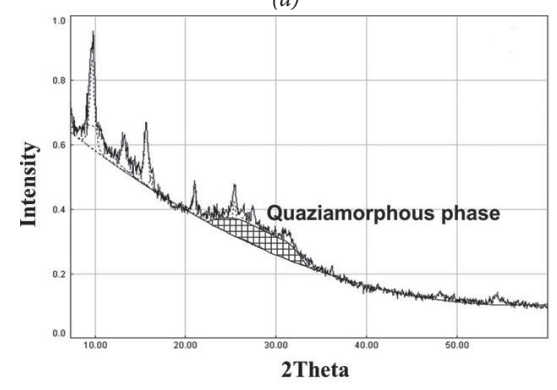

(b)

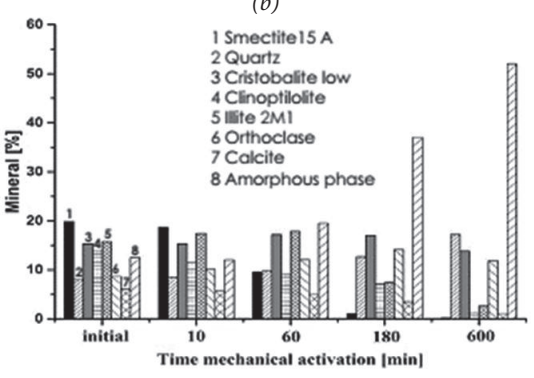

(c)

Fig. 6. X-ray diffraction patterns of zeolites during 5 minutes milling time, for (a) SAPO-34, (b) for SCT-323, mineralogical composition of natural zeolite during mechanical activation (c)

6. ábra 5 perces mechanikai aktiváláson átesett minták röntgendiffrakciós görbéi (a) SAPO-34, (b) SCT-323 és (c) a természetes zeolit ásványi összetételének változása az örlési idö függvényében

\section{Conclusion}

The mechanical activation of the natural zeolite corresponds to the curve of the developed specific surface as function of the milling time. It has been shown that during the first 60 minutes, the specific surface area increases, reaching a maximum, after which a sharp decrease occurs. Mechanical activation of synthetic zeolite powders corresponds to the agglomeration zone due to the small particle size of SAPO-34 and SCT-323. For synthetic zeolites are observed fast and sharp decrease specific surface area of the zeolites decreases during the milling.
During the mechanical activation it was observed an increase of system amorphisation by $8-10 \%$ for synthetic zeolites, by 40 $45 \%$ for natural zeolite.

\section{Acknowledgement}

This work was carried out with partial support of project No. 5.2352.2017/4.6 of the Ministry of Education and Science RF in accordance with Tomsk State University's competitiveness program

\section{References}

[1] Feng, C. - Khulbe, K. C. - Matsuura, T. - Farnood, R. - Ismail, A.: F 2015 JMSR 149

[2] Akimkhan, A. M. (2012): Structural and Ion-Exchange Properties of Natural Zeolite (Croatia:Intech)

[3] Buzimov, A. - Kulkov, S. - Kurovics, E. - Eckl, W. - Pappert, S. (2017): IOP Conf. Series: Mater. Sci. Eng. 175012033 https://dx.doi.org/10.1088/1757-899X/175/1/012033

[4] Olson E 2012 J. of GxP Compliance 1652

[5] Tariq, F. - Rafique, U. - Yaqoob, K. (2017): Épitőanyag-JSBCM 69 (3) 94 https://dx.doi.org/10.14382/epitoanyag-jsbcm.2017.16

[6] Khramchenkov, M. G. - Usmanov, R. M. (2017): Épitőanyag-JSBCM 69 (4) 110. https://dx.doi.org/10.14382/epitoanyag-jsbcm.2017.19

[7] Nikashina, V. A. - Streletskii, A. N. - Meshkova, I. N. - Kolbanev, I. V. Grinev, V. G. - Serova, I. B. (2011): Inorganic Materials 471341

[8] Geber, R. - Kocseha, I. - Gömze, L. A. (2012): Mater. Sci. Forum 729344

[9] Kandeel, A. M. (2015) Épitőanyag-JSBCM 67 (3) 98 http://dx.doi.org/10.14382/epitoanyag-jsbcm.2015.16

[10] Mucsi, G. (2016): Épitőanyag-JSBCM 68 (2) 56 http://dx.doi.org/10.14382/epitoanyag-jsbcm.2016.10

[11] Gömze, L. A. (2010): Mater. Sci. Forum 65919 www.scientific.net/MSF.659.19

[12] Juhász, Z. A. - Opoczky, L. (2003): Épitőanyag-JSBCM 55 (3) 86 http://dx.doi.org/10.14382/epitoanyag-jsbcm.2003.16

[13] Urakov, A. L. (2015): Épitőanyag-JSBCM 67 (1) 2 http://dx.doi.org/10.14382/epitoanyag-jsbcm.2015.1

\section{Ref.:}

Buzimov, Alexandr Y.- Eckl, Wilhelm- Gömze, László A.- Kocserha István- Kurovics, Emese- Kulkov, Aleksey S.- Kulkov, Sergei N.: Effect of mechanical treatment on properties of Si-Al-O zeolites

Építőanyag - Journal of Silicate Based and Composite Materials, Vol. 70, No. 1 (2018), 23-26. p.

https://doi.org/10.14382/epitoanyag-jsbcm.2018.5

\section{A Si-Al-0 zeolitok mechanikai tulajdonságai}

A szerzők ismertetik a mechanikai aktiválás hatását a Tokaj környéki természetes zeolitok és a SAPO-34, SCT-323 szintetikus zeolitok morfológiájára, fajlagos felületére és fázisösszetételére. A szintetikus zeolitoknak bolygó golyósmalomban történó mechanikai aktiválása során csökken a fajlagos felülete; míg a természetes zeolitok fajlagos felületének változása függ az ôrlési idôtôl (Rittinger-, aggregációs-és agglomerációs szakasz). A mechanikai aktiválást követôen a rendszerben található amorf fázis aránya a szintetikus zeolitok esetén 8-10\%, a természetes zeolitoknál pedig eléri a 40-45\% nagyságot. A kapott eredmények nagy gyakorlati jelentôséggel bírnak, egyben a zeolitok további vizsgálatainak az alapját képezik.

Kulcsszavak: kristályszerkezet, mechanikai aktiválás, morfológia, röntgendiffrakció, zeolit 